\title{
Trade Conflict Between the U.S. and China: What Are the Impacts on the Chinese Economy?
}

\author{
S. Park
}

Sang-Chul Park - Professor at Graduate School of Knowledge Based Technology and Energy, Korea Polytechnic University; 429-793, Kyonggi-Do, Siheung-City, 2121 Jeongwang-Dong, Korea; tel: +82 318041 0324 (O); E-mail: scpark@kpu.ac.kr

\begin{abstract}
A trade growth has slowed down in the global economy since the global financial crisis in 2008. It seemed to recover in 2017, but declined again since the Trump Administration in the USA posed trade protectionism in 2018 that led trade conflicts with its major trade partners such as Canada, China, Japan, Mexico, South Korea, the EU. Among these partners, the USA amended FTAs with Canada, Mexico, and South Korea by negotiations. It still negotiates FTA with Japan. However, the US government took a different approach to China in terms of tradethat is based on a hard line for setting high tariffs on Chinese import goods. China also responded with high tariffs on US import goods. As a result, the trade conflict started by criticizing each other, while the US represents its national interest first and China indicates the global free trade system as a key issue. In reality, the trade conflict has influenced not only the US and Chinese economy, but also the whole global economy negatively because the two economies as G2 accounted for nearly 40 percent of the global outcome. Therefore, it is one of the most sensitive issues on the global economic growth how it will affect to the global economy further. This paper argues why the trade conflict has emerged and how to solve it. It also focuses on economic impacts of the trade conflict on the global economy in general and Chinese economy in particular. Furthermore, it analyzes how the Chinese government deals with trade negotiations with the USA strategically.
\end{abstract}

Key words: trade protectionism; trade conflict; economic impacts; Chinese economy; world economy

For citation: Park S. (2020) Trade Conflict Between the U.S. and China: What Are the Impacts on the Chinese Economy? International Organisations Research Journal, vol. 15, no 2, pp. 153-168 (in English). DOI: 10.17323/19967845-2020-02-10

\section{Introduction}

The U.S. has been facing challenges due to the rise of China since China became the second largest economy in 2010. After the economic reform in 1978 named as the open policy, China's economic scale and foreign trade have been growing rapidly. As a result, Chinese economy surpassed German economy in 2009 and continuously Japanese economy in 2010 that was rather dramatic and very fast. China's role in the global economy has grown to be even more significant particularly since the global financial crisis (GFC) in 2008. It is widely recognized that the bilateral relationship between the U.S. and China will be a crucial determinant of the world's direction in the $21^{\text {st }}$ century because China has tried to build a new form of cooperative platform in world politics and global economy by creating G2 in 2013. Since then, the U.S. and China started to open G2 Summit annually under the Obama government, but it stopped in the Trump government [Hsieh, 2009; Kirton, 2013; Park, 2017].

In order to play its roles properly in the global economy, China requested for additional voting rights in the International Monetary Fund (IMF) in the G20 Summit in 2009that could increase its political and decision making power within the IMF. In 2016, the Chinese cur- 
rency, Yuan, officially joined the Special Drawing Rights (SDR) basket and became one of the foreign exchange reserve currencies of the IMF along with U.S. Dollar, British Pound, Euro, and Japanese Yen. Furthermore, the quota of China in the IMF increased 30.5 billion SDRs in 2017 that increased from 1.8 billion SDRs in 1980. As a result, its total vote share increased to 6.09 percent. The currency composition of the SDR basket is reviewed every five years, and the current weights for the component currencies are U.S. dollar (41.73 percent), Euro (30.93 percent), Chinese Yuan (10.92 percent), Japanese Yen (8.33 percent), and British Pound (8.09 percent) [Momani, 2016; IMF, 2015].

Although the Chinese voting rights in the IMF are still weaker than those of the U.S. and the EU, its economic power has already been the second largest economy in the world since 2010. With the high economic growth of 6.6 percent in 2018, not only the U.S., but also the EU officially announced China as an economic competitor in the pursuit of technological leadership and a systemic rival promoting an alternative model of governance. The EU urged that China is no longer regarded as a developing country, but a key global actor and leading technological power. Therefore, China should take more responsibilities for upholding the rules based on international order and greater reciprocity, non-discrimination, and openness of its system. For it, China publicly stated reform must be carried out into policies, and actions commensurate with its role and responsibility [European Commission, 2019].

With the rise of China as G2, it is significant to understand the bilateral trade relations between the U.S. and China and the impacts of the two nations' increasing interdependence on the global economy. Several negative perspectives on the trade conflicts between the U.S. and China had been already expressed in the mid of 2000s. The major reason for the proliferation of trade conflicts between the G2 was based on the U.S.'s large trade deficit with China that may lead to a trade war between the two nations. The terms of trade war refer to an economic conflict caused by the fact that one nation imposes trade restrictions against the other nation promoting to retaliate by imposing higher tariffs or non-tariff barriers. As a result, it leads to a deterioration of bilateral trade relations [Stewart, 2006; Bezlova, 2007; Hsieh, 2009; Park, 2017].

Such a trend has continued through all U.S. presidencies and led to protectionism since the Trump Administration. The U.S. and China realized the trade conflicts as trade war although the both parties are negotiating to solve the trade conflicts. China has noticed fundamental changes of the U.S. government on Chinese political and economic power. The U.S. considers China as a serious threat to the U.S. global interests. It also rules out the possibility of China reforming gradually towards the Western system that resulted in a comprehensive review of past decades' US policy towards China. Accordingly, the core reason of the trade conflicts between the two nations is not only because of the economy, but also due to the politics in order to gain the global hegemony. It means that escalation of conflicts and confrontation is inevitable for the two nations in the long term perspective [Chin et al., 2018].

This paper argues when and why the trade conflict between the U.S. and China started. It also analyzes what may be impacts of the trade conflict between the two nations on the global economy as a whole and on Chinese economy in particular as well as how to solve the trade friction. Furthermore, it suggests how to prevent the possible trade conflicts based on protectionism in the future. In order to find answers of these questions, critical analysis of literature, inference and cross sectional analysis based on statistical data are employed.

\section{Theoretical Debates}

Most of economists would agree with recent rebuttals to skepticism about the liberal trading order because of widely and rapidly spreading protectionism around the world. However, it is the fact that the intellectual and political support for free trade in the U.S. and elsewhere seems 
to have been weaken since the GFC in 2008. At the same time, protectionism has started since then although G20 member nations agreed to prevent it at the G20 Summit in Washington D.C. Therefore, free trade based on multilateralism is regarded as a wishful thinking for many countries particularly in the U.S. since the Trump Administration [Hufbauer, Schott, 2008].

Economic theory suggested comparative advantage and economies of scale would create economic gains through economic efficiency. Therefore, tariffs led to competitive tariff retaliation, which result in a massive shrinkage in foreign trade and low global economic growth. Economic theory never urged that free trade is good for all industries and all people. However, the winners from the free trade can afford to compensate the losers and every one could be made better off because the aggregate gains are positive [O'Rourke, Williamson, 2001; Rosen, 2008].

Economic theory also says that resources will flow to more efficient uses. However, it does not apply when governments and markets do not work well. Therefore, Samuelson already urged in 1972 that the aggregate gains from trade are not necessarily positive for all nations. He expanded his idea further to claim that growth in the rest of the world can damage a country if it takes place in sectors that compete with its native exports having comparative disadvantage. As a result, relative and even absolute a nation's GDP per capita can fall in such a condition. Gomory and Baumol extended Samuelson's theory and urged that there ismuch possible equilibrium with vastly different outcomes for the countries involved in a modern free trade world. They stated further that it is perfectly possible or rather common for a nation's equilibrium trade outcome to be less than the self-sufficiency outcome. Accordingly, good equilibrium is often created rather than bestowed by nature. As a result, countries can do much to affect their trading outcomes. Therefore, they urge US protectionism in trade [Samuelson, 2004; Gomory, Baumol, 2009].

However, Bhagwati criticizes that Samuelson's explanation cannot be used as a justification for US protectionism. He also denies Gomory and Baumol's argument because the U.S. could not carry out effective industrial policies to remedy it although their argument is true. Krugman and Obsfeld support Bhagwati's critics that it is an empirical question rather than a fact whether the growth of emerging economies has actually hurt advanced countries although theoretical possibility still exists [Bhagwati, 2009; Krugman, Obsfeld, 2009].

Economists have developed theoretical models for free trade and estimated welfare gains from reducing or eliminating trade barriers. In line with these models, Krugman, and Broda and Weinstein suggested that trade benefits society through gains overall quality and variety. However, this standard static growth from the free trade has left trade promoters quite vulnerable because the static growth models consider only the short run partial equilibrium efficiency gains. At the same time, the static models generate the gains from trade range very marginal [Krugman, 1997; Broda, Weinstein, 2006].

In order to deepen theoretical models finding long term efficiency gains and contribution of free trade to economic growth, economists have developed dynamic models estimating impacts of trade liberalization used by cross country regressions. By using these models, Bradford et al. urged that the US economy in 2005 could generate higher economic growth than without post war trade liberalization. However, Acemoglu left the issue of trade and growth undecided because there are models that highlight both positive and negative effects of trade on economic growth so that empirical work must be conducted. Accordingly, Lewer and Van den Berg pointed out that further development of dynamic models and additional empirical research are required. Additionally, linkages between trade and technology as well as trade and institutional quality must be further developed [Bradford et al., 2006; Acemoglu, 2009; Lewer, Van den Berg, 2007; Feenstra et al., 2009].

In this paper, the dynamic models rather than static models can be adopted because the former can explain the long term benefits of the free trade more precisely than the latter. Ac- 
cordingly, the conservative dualism of trade theory explains why the U.S. protectionism has emerged since the global financial crisis. It represents the Trump government trade policy than any other theoretical background. However, it has limited to generate the global economic growth sustainable. Therefore, it is possible that the dynamic models based on the long term efficiency gains and economic growth can correct the direction of protectionism toward the free trade. It is the reason why the U.S. and China have started the trade negotiation since 2018 and its outcome may be visible in the near future.

\section{Trade Conflicts Between the U.S. and China}

\section{Background}

The large size of the trade deficit between the U.S. and China has been a significant issue in bilateral trade relations. The Trump Administration regards the trade deficit with China as a sign of unfair economic policies in China although the U.S. government has suffered from its chronic budget deficit since the 1980s. Therefore, it has reportedly request China to develop a plan to reduce the bilateral trade deficit targeting by $\$ 100$ billion. However, there is a large difference between the two nations' view on their official trade statistics. According to the U.S. trade statistics in 2017, the merchandise trade deficit with China accounted for $\$ 375.3$ billion, while Chinese trade surplus with the U.S. in the same year was $\$ 275.8$ billion. Nearly $\$ 100$ billion difference exists between the two nations that could cause a serious dispute between the two parties. However, a statistical working group established by the U.S. - China Joint Commission on Commerce and Trade (JCCT) in 2004 identified the causes of the statistical discrepancies that does not mean any error in the official statistics of either country [Martin, 2018].

In fact, the U.S. has had the largest trade deficit in the world over three decades since the 1970s. Exceptionally, the U.S. had briefly a trade surplus in the mid of 1970s, but has experienced continuous deficit since then. The U.S. deficit increased over 5 percent of the national GDP in 2005 and fell to 2.9 percent of the national GDP in 2017. Owing to the rapidly increase of the U.S.'s aggregate trade deficit, the Trump government criticized major U.S. trade partners generally and China in particular. The U.S. argues that China must correct its unfair trade policies generating huge trade surpluses with the U.S. that creates the trade imbalances between the two nations [Genereux, 2017; WTO, 2018; Park, 2018].

\section{Development and Current Situation of Trade Conflicts}

After a longer than six decades' free trade movement, the U.S. has recently shaken the foundations of the global trading system by imposing steep tariffs on imports from China and other major trading partners since President Trump took the power in 2017. The trade conflicts between the U.S. and other major trading partners in general and China in particular started as the US International Trade Commission (USITC) found that imports of solar panels and washing machines caused injury to the US solar panel and washing machine industries in Oct. and Nov. 2017 respectively. The two U.S. industries filed separate requests for the investigations in early 2017 under Section 201 of the Trade Act of 1974 that were the first industry petitions since 2001.

As a result, President Trump approved global safeguard tariffs on $\$ 8.5$ billion in imports on solar cells and modules and \$1.8 billion of large residential washing machines in Jan. 2018 that were imposed beginning on 7 Feb. 2018. As a counter measure, the Chinese government requested to have consultations with the U.S. under the WTO dispute settlement framework concerning these imports. Moreover, the Chinese government announced preliminary antidumping duties of 
179.6 percent on imports of U.S. agricultural product, sorghum and imposed preliminary tariffs in April 2018. Chinese tariffs on US sorghum ended during negotiation in May 2018, and China also filed WTO dispute against U.S. solar panel tariffs in Aug. 2018. This signaled the significant trade conflict between the two parties that started the macroeconomic impact on the global economy negatively [Bown, Kolb, 2018; Ng, Chung, 2018; Bolt et al., 2019].

Moreover, the Trump Administration imposed tariffs on imports of steel with 25 percent and aluminum with 10 percent in Feb. 2018 under name of threatening the U.S. national security based on Section 232 of the Trade Expansion Act of 1962. Chinese portion covered only 6 percent of imports due to prior US imposition of antidumping and countervailing duties. Therefore, the Chinese retaliatory tariffs on this issue only accounted for $\$ 3$ billion. China also imposed tariffs on various imports from the U.S. that included 128 tariff lines.

In addition to steel and aluminum, President Trump imposed 25 percent tariffs on 1,333 Chinese products in two phases starting July 2018 that accounted for $\$ 50$ billion targeted intermediate inputs and capital products because U.S. Trade Representative (USTR) found that China conducted unfair trade practices related to technology transfer, intellectual property, and innovation that was investigated under Section 301 of the Trade Act of 1974. China also issued an updated $\$ 50$ billion retaliation list of 25 percent tariffs including agricultural and food products, crude oil, automobiles, airplanes, chemical products, medical equipment and energy products etc. in two phases that accounted for 659 tariff lines. Since then, trade conflicts between the two parties have continued, and President Trump directed the USTR to identify an additional \$200 billion of Chinese imports for additional tariffs of 10 percent in response of Chinese retaliatory tariffs in June 2018. The USTR finalized the tariff list containing 5,745 full or partial lines of the original 6,031 tariff lines that were on a proposed list of Chinese imports. The additional tariff was effective starting in Sep. 2018 [Bown, Kolb, 2018; McLarty Associates, 2018; Ng, Chung, 2018; USTR, 2018].

Since the additional tariff of 10 percent on $\$ 200$ billion of Chinese imports, the ongoing trade conflict between the two nations has continued. Amid the trade conflict, the U.S. government threatened to impose tariffs as high as 25 percent on all U.S imports from China if China implements its further retaliation measures. President Trump decided on increasing the tariffs to 25 percent on $\$ 200$ billion of Chinese imports in May as the trade negotiation between the two nations was not met. As a result, China also responded its retaliation measure to set the high tariff up to 25 percent on $\$ 60$ billion of U.S. imports. Due to the ongoing trade conflict, the neighboring countries of China such as Japan, South Korea, Thailand, and Vietnam suffer from a stiff decline of their exports to China although their exports to the U.S. increases at the same time. Additionally, China started to consider all options to strike back by targeting large-sized US corporations operating in China. It was announced after the U.S. government prepared more tariffs on imports of China and banned Chinese high-tech firm, Huawei [Bolt et al., 2019; Strauss, 2019; Cong, 2019].

During the trade conflict, the U.S. government has considered to raise the tariffs on all imports of automobiles and auto parts that could impact on the global economy massively. It could raise the risk of spreading the trade conflict at a global scale and escalating retaliation measures all over the world. However, the Trump Administration announced a delay of its final decision on whether to impose broad tariffs on automobile and auto part imports for about six months right after imposing the tariff of 25 percent on $\$ 200$ billion of Chinese imports. If the tariffs on all imports of automobiles and auto parts are realized, the U.S. major trade partners such as Germany, Japan, South Korea, China, Mexico etc. will be affected severely that could result in a global economic slowdown. In fact, the global trade conflict started due to the high U.S. trade deficit from China and other major trade partners. However, at the same time, the U.S. high tariffs imposing against the U.S. major trade partners in general and China in particular have intensified the global trade conflict further [Salama, Mauldin, 2019, table 1]. 
Despite the harsh trade conflicts, the two largest economies finally agreed the trade deal in Dec. 2019 and signed on it in Jan. 2020. It could change the economic relationship between the U.S. and China significantly. The agreement includes that China has committed to buy an additional $\$ 200$ billion of the U.S. goods and services by 2021 and ban on illegal business practices that the U.S. government has criticized. However, the accord does not provide information about how to work in practices. Therefore, it is possible that China could interpret text of the accord differently than the U.S. It is the reason why the second trade war between the two parties may be possible in the future [Eavis et al., 2020; Office of the United States Trade Representative \& Department of Treasury, 2020].

Table 1. Category and Content of US Trade Conflicts With Major Trading Partners

\begin{tabular}{|l|l|}
\hline \multicolumn{1}{|c|}{ Category } & \multicolumn{1}{c|}{ Content } \\
\hline Solar Panels and Washing Machine & $\begin{array}{l}\text { Imposing safeguard tariffs on \$8.5 billion in solar panels and \$1.8 billion in } \\
\text { washing machines. } \\
\text { Chinese preliminary tariffs on US sorghum \& filing WTO dispute against US } \\
\text { solar panels tariffs. } \\
\text { Korean filing WTO dispute against US solar panels and washing machines } \\
\text { tariffs }\end{array}$ \\
\hline $\begin{array}{l}\text { Steel and aluminum as national security } \\
\text { threat }\end{array}$ & $\begin{array}{l}\text { Section 232 of Trade Expansion Act of 1962. } \\
\text { 25 percent on steel \& 10 percent on aluminum covering \$48 billion of imports }\end{array}$ \\
\hline $\begin{array}{l}\text { Unfair trade practices for technology } \\
\text { \&intellectual property (IP) }\end{array}$ & $\begin{array}{l}\text { Section 301 of Trade Act of 1974. } \\
\text { \$50 billion of 1,333 Chinese products for 25 percent tariffs with two phases. } \\
\text { Identifying \$200 billion for 10 percent tariffs in Sep. 2018. } \\
\text { Raising tariff to 25 percent on \$200 billion in May 2019 }\end{array}$ \\
\hline Auto vehicles as national security threat & $\begin{array}{l}\text { Announcing to raise tariffs up to 25 percent and delay six months in 2019 } \\
\text { mainly against the EU, Japan and South Korea }\end{array}$ \\
\hline
\end{tabular}

Source: [Bown, Kolb, 2018; McLarty Associates, 2018; Ng, Chung, 2018; USTR, 2018; Salama, Mauldin, 2019; Strauss, 2019].

\section{Reasons for the Trade Conflict Between the U.S. and China}

There are many reasons for trade conflicts whenever these take place regardless of between nations and regions. Among these, the trade conflict between the two largest economies can be explained with the following four reasons that are claimed by the two parties commonly and observed by the outsiders. These are trade imbalance between the two nations, US protectionism based on income inequality and chronic budget deficit, China's unfair trade against intellectual property right (IPR), technology transfer and innovation for US companies, and competition of hegemony power in the $21^{\text {st }}$ century.

Firstly, the U.S. trade deficit with China accounted for \$419 billion in 2018 that increased from \$376 billion in 2017 although the Trump Administration imposed high tariffs on imports goods from China. The share of U.S. trade deficit with China in 2018 accounted for nearly 42 percent of the total U.S. trade deficit although it declined from 49 percent in 2015. The U.S. imported $\$ 540$ billion from China in 2018, while it exported $\$ 120$ billion to China in the same year. The three biggest categories of the U.S. imports from China were computers and accessories, cell phones, and apparel and footwear that accounted for $\$ 77$ billion, $\$ 70$ billion, and $\$ 54$ billion respectively. The three largest US exports to China were commercial aircraft, soybeans, and autos that accounted for $\$ 16$ billion, $\$ 12$ billion and $\$ 10$ billion respectively. It indicates that the U.S. trade deficit with China is not a short term based phenomena, but a long term based chronic trend due to the different industrial structures between the two nations. As a 
result, the U.S. trade deficit increased from $\$ 273$ billion in 2010 to $\$ 419$ billion in 2018 continuously [Amadeo, 2019; Park, 2018; United States Census Bureau, 2019, fig. 1].

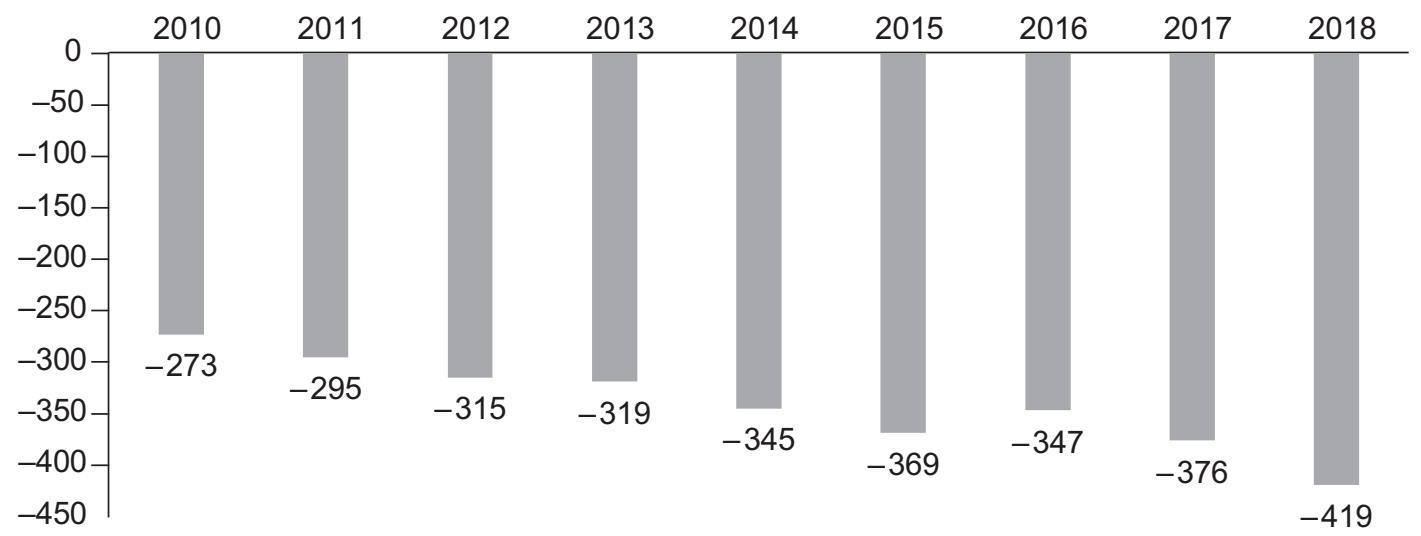

Trade deficit

Fig. 1. The U.S. Trade Deficit with China from 2010 to 2018 (As of USD billion)

Source: [United States Census Bureau, 2019].

Secondly, the U.S. as the largest economy in the world has led to protectionism since the GFC in general and the Trump Administration in particular that has affected to the global economy severely. The U.S. protectionism impacts on the global economy negatively due to its economic size compared with other economies. It results mainly from the income inequality and distribution as well as a vast government budget deficit in the U.S. that has risen since the 2000s. However, economists are not sure yet whether the free trade has created the income inequality and the budget deficit or not. Some economists urged that the free trade affected only about 20 percent of increase in inequality in the 1970s and 1980s when the U.S. trade was mostly North to North. With the shift of trade relations to North to South, a more negative impact on the wage of low skilled workers in the U.S. took place since the 1990s. Whatever the cause of rise in inequality, the fact is that the average of real wage of production per hour has been stagnant since the 1980s. As a result, the wage increase in production has lagged behind the growth in real GDP per capita. Moreover, the share of pre-tax income in the top one percent increased from 10.5 percent in 1980 to over 20 percent in 2016, while its share of bottom 50 percent declined from 20.5 percent to 13 percent during the same period. It may have caused a lower tax revenue. As a result, it led the U.S. as the most inequality nation among the advanced countries based on Gini index that increased up to 0.41 in 2016 [Krugman, 2009; ERP, 2009; Hillebrand et al., 2010; OECD, 2014; Piketty, 2014; Alvaredo et al., 2017; World Bank, 2019, fig. 2].

Thirdly, President Trump asked US Trade Representative (USTR) to investigate whether Chinese laws, policies, practices that may harm US intellectual property rights, innovation or technology development in Aug. 2017 or not, and the USTR initiated investigation of China under Section 301 of the Trade Act of 1974. It found that China conducted unfair trade practices related to technology transfer, intellectual property, and innovation so that President Trump imposed 25 percent tariffs on 1,333 Chinese products in two phases starting July 2018 that accounted for $\$ 50$ billion targeted intermediate inputs and capital products. China also retaliated with an updated $\$ 50$ billion list of 25 percent tariffs including agricultural and food products, 
crude oil, automobiles, airplanes, chemical products, medical equipment and energy products etc. in two phases that accounted for 659 tariff lines [Ng, Chung, 2018; USTR, 2018].

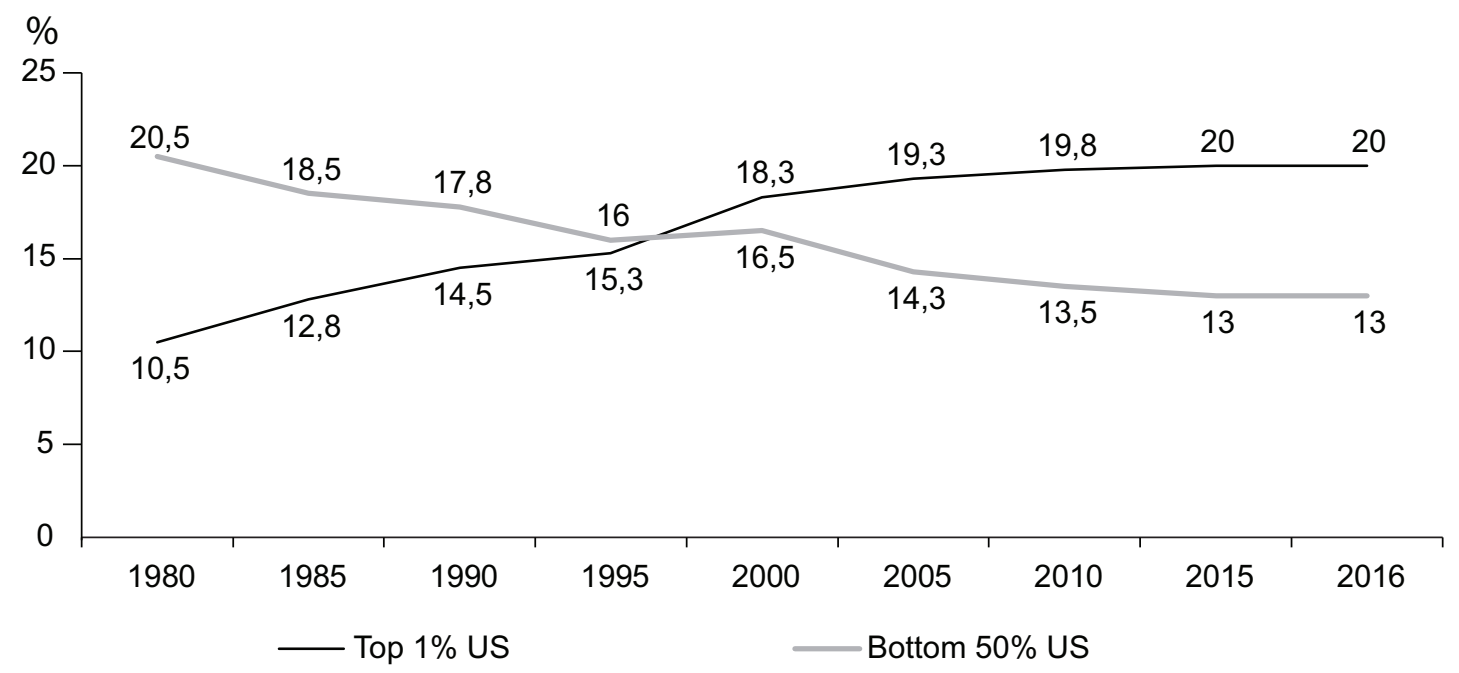

Fig. 2. Share of Pre Tax Income in the U.S. (As of 1980-2016)

Source: [Alvaredo et al., 2017].

Last, but not least the U.S. - China trade conflict is based on the competition of a hegemony power in the $21^{\text {st }}$ century. Therefore, several scholars expect that it would take a long term instead of a short term. In the national security strategy report in 2017, the U.S. called China as its strategic rival. Additionally, the U.S. government particularly concerned the Chinese national development strategy, the Made in China 2025 program as a national threat in terms of high tech development that plays the core role in strengthening Chinese future competitiveness. In line with such a strategic point of view on the high tech area, President Trump signed on the executive order to ban the Chinese high tech firm, Huawei in May 2019 that is one of the leading global telecommunication companies in 5G technology in the world along with Ericsson, Nokia, and Samsung Electronics. The 5G technology is the key technology to realize the Fourth Industrial Revolution connecting the physical and cyber world. At present, China is one of the leading countries in this field ahead the U.S. that the U.S. government concerns mostly. If China succeeds the Fourth Industrial Revolution based on the 5G technologies, the U.S. technological supremacy will be over, and China will be the game changer in the world. Therefore, the key issue on the trade conflict between the two parties is rather politics than economics that escalate confrontation between the two nations continuously in the future [Schwab, 2016; The White House, 2017; Chin et al., 2018; Jiming, 2018; Doffman, 2019].

\section{Analysis on Impacts of the Trade Conflict}

\section{Trade Conflict and Tariff Measures}

Impacts of the trade conflict are not only bilateral, but also global. Particularly, the two largest economies in the world generate two fifths of global GDP and about a quarter of global trade. Therefore, the bilateral trade conflict between the U.S. and China is worrisome for both 
the region and the world because the two nations are two of the three main hubs for global production chains along with the European Union (EU) with tight trade links in key industrial sectors such as electronics and high technology equipment [Abiad et al., 2018].

Most of the products affected in the first two rounds of bilateral tariffs imposed on imports of Chinese goods for $\$ 50$ billion are mainly capital and intermediate goods that are targeted for the Made in China 2025 plan. In order to meet the target of the plan, China needs to import high tech products for its end-products. These products are deeply connected with global value chains. By contrary, China retaliated to impose tariffs mostly on imports of the U.S. agricultural products, chemicals, medical and energy equipment. These products are rather homogeneous goods available in the global markets.

The second round of the trade conflict of $\$ 200$ billion by the U.S. and $\$ 60$ billion tariffs by China started in the mid of 2018 that affected to consumer goods because fewer supply chain lines were left to set the targets. The trade tension between the two nations escalated continuously, and the U.S. threatened to impose tariffs of another $\$ 267$ billion on Chinese imports. It was all goods imported from China in 2018. China also threatened to retaliate with similar tariffs on all imports from the U.S. It also considers other measures to retaliate the U.S. companies operating in China. In the global trade tension, the U.S. government has considered to set the tariff of 25 percent on imports of automobiles and auto parts from all trading partners that would affect $\$ 350$ billion worth of goods [Abiad et al., 2018; Park, 2018].

\section{Impacts on the U.S. and Chinese Economy}

The escalation of trade conflict and threats between the two nations caused a significant pressure of outlook for the global economic growth in general and the Chinese economy in particular. The Chinese export and sales started already weak in the third quarter of 2018. Additionally, the threats influenced investors in a wait and see mode and accelerated restrictions of foreign direct investment (FDI) for the high tech areas from China and vice versa [Hanemann, 2018].

In order to analyze impacts of the trade conflict on the two economies, it is reasonable to adopt studies of global research institutes providing objective and independent analyses, which are not influenced by the U.S. and China. One of these is the report of Asian Development Bank (ADB) that analyzes the implications of three scenarios. The first scenario is a current scenario including all trade measures implemented as of Oct. 2018 with $\$ 200$ billion of imports from China in 25 percent of tariffs. The second one is a bilateral escalation scenario intensifying to impose blanket tariffs of 25 percent on all merchandise imports from the both countries. Finally, the last scenario is a worst case scenario including measures under the bilateral escalation scenario and a global escalation of trade conflict between the U.S. and other trading partners in automobiles and parts imposed by the U.S. on 25 percent tariffs of imports from other nations (see table 2).

The immediate impact of these three scenarios will take time to be materialized fully. The current scenario will be affected fully in 2019, while the direct impact of the worst scenario will approach nearly a full effect in 2020 . The worst scenario could be completed in 2021 if the trade deal between the two economies could not be made successfully. Moreover, the scenario modeling is used by the ADB Multiregional Input-Output Table (ADB MRIOT) for the year 2017 in order to quantify the impact of changes in tariffs working through local and production chains that provides advantages in individual economies and sectors as well as understanding the structure and evolution of global value chains. The direct impact of the trade conflict 
is quantified at product level gathered by published lists of tariff affected commodities for all countries involved in the trade conflicts as of Sep. 2018. Additionally, these commodities are matched with detailed trade data from BACI and the United States Census Bureau in 2017 that uses a 6- to 10-digit Harmonized System classification [Abiad et al., 2018; Wang et al., 2018].

Table 2. Description and Size of Three Modeled Scenarios Between the U.S. and China

\begin{tabular}{|c|c|c|c|}
\hline Scenarios & US Tariff Actions and Size of Impact & Retaliatory Measures by China & Date of Implementation \\
\hline \multirow[t]{4}{*}{$\begin{array}{l}\text { Current Scenario } \\
\text { (measures } \\
\text { implemented as of } \\
\text { Oct. 2018) }\end{array}$} & $\begin{array}{l}30 \% \text { and } 20 \% \text { blanket tariffs on all } \\
\text { imports of solar panels and wash } \\
\text { machines worth } \$ 10.3 \text { billion ( } 0.4 \% \\
\text { of US imports) }\end{array}$ & $\begin{array}{l}\text { China imposed } 15 \% \text { and } 25 \% \\
\text { tariffs on } \$ 3 \text { billion worth of US } \\
\text { goods ( } 2.3 \% \text { of US exports to } \\
\text { China) }\end{array}$ & First quarter 2018 \\
\hline & $\begin{array}{l}25 \% \text { on } \$ 34 \text { billion worth of Chinese } \\
\text { goods ( } 7 \% \text { of Chinese exports to the } \\
\text { US) }\end{array}$ & $\begin{array}{l}25 \% \text { on } \$ 34 \text { billion worth of US } \\
\text { goods ( } 26 \% \text { of US exports to } \\
\text { China) }\end{array}$ & 6 July 2018 \\
\hline & $\begin{array}{l}25 \% \text { on } \$ 16 \text { billion worth of Chinese } \\
\text { goods ( } 3 \% \text { of Chinese exports to the } \\
\text { US) }\end{array}$ & $\begin{array}{l}25 \% \text { on } \$ 16 \text { billion worth of US } \\
\text { goods }(12.3 \% \text { of US exports to } \\
\text { China) }\end{array}$ & 23 Aug. 2018 \\
\hline & $\begin{array}{l}10 \% \text { on } \$ 200 \text { billion worth of } \\
\text { Chinese goods raised to } 25 \% \text { in } 2019 \\
\text { ( } 40 \% \text { of Chinese exports to the US) }\end{array}$ & $\begin{array}{l}5 \%, 10 \%, 20 \% \text { and } 25 \% \text { on } \$ 60 \\
\text { billion worth of US goods ( } 46 \% \\
\text { of US exports to China) }\end{array}$ & $\begin{array}{l}\text { Begins } 24 \text { Sep. } 2018 \text { and } \\
\text { escalates 1 June } 2019\end{array}$ \\
\hline \begin{tabular}{l|} 
Bilateral Escalation \\
Scenario (add $25 \%$ \\
tariffs on all bilateral \\
US China imports)
\end{tabular} & $\begin{array}{l}\text { US blanket tariffs of } 25 \% \text { on } 100 \% \\
\text { of Chinese exports to the US worth } \\
\$ 505.5 \text { billion (an additional } \$ 267 \\
\text { billion from previous scenario) }\end{array}$ & $\begin{array}{l}\text { Chinese blanket tariffs of } 25 \% \\
\text { on } 100 \% \text { of US exports to China } \\
\text { worth } \$ 130 \text { billion (an additional } \\
\$ 17 \text { billion added from previous } \\
\text { scenario) Chinese blanket tariffs } \\
\text { of } 25 \% \text { on } 100 \% \text { of US exports } \\
\text { to China worth } \$ 130 \text { billion (an } \\
\text { additional } \$ 17 \text { billion added from } \\
\text { previous scenario) }\end{array}$ & $\begin{array}{l}\text { Model assumed first } \\
\text { quarter 2019, but } \\
\text { delayed after second } \\
\text { quarter }\end{array}$ \\
\hline $\begin{array}{l}\text { Worst Case Scenario } \\
\text { (add } 25 \% \text { tariff on } \\
\text { all autos, parts } \\
\text { and retaliation) }\end{array}$ & $\begin{array}{l}\text { US blanket tariffs of } 25 \% \text { on all } \\
\text { imports of autos worth } \$ 350 \text { billion } \\
\text { (14.5\% of US imports equivalent to } \\
0.44 \% \text { of global GDP }\end{array}$ & $\begin{array}{l}\text { Retaliatory measures by other } \\
\text { countries including China on all } \\
\text { their auto and auto parts imports } \\
\text { from the US worth } \$ 130 \text { billion } \\
\text { ( } 6.8 \% \text { of total US merchandise } \\
\text { exports) }\end{array}$ & $\begin{array}{l}\text { Model assumed first } \\
\text { quarter 2019, but delays } \\
\text { third quarter } 2019\end{array}$ \\
\hline
\end{tabular}

Source: Author's own adaptation based on [Abiad et al., 2018].

Given the ADB analysis, the trade conflict between the two economies will be affected negatively in all scenarios. Under the current scenario, the Chinese economy would grow lower GDP by 0.48 percent, while the bilateral escalation scenario subtracts 0.55 percent GDP. In the worst case scenario, the Chinese economic growth could be less by 1.05 percent. By contrary, the U.S. economy could be affected by the trade conflict less than the Chinese economy. It could subtract 0.12 percent, 0.08 percent, and 0.24 percent respectively. It indicates that the trade conflict can impact on the two major economies rather marginal than expected in the midterm period although its impacts on Chinese economy are much higher than on the U.S. economy (see fig. 3, 4).

Another report analyzed by the Netherlands' government research institute represents the EU's perspective on the trade conflict between the U.S. and China. Given the longer term analysis of the baseline in 2030 on the trade conflict scenarios from World Scan simulations as the CPB's global CGE model, the macroeconomic results look similar. The baseline is in 2018 
when business is as usual scenarios with no trade policy change and a trade shock with negative GDP effects due to the tariff increase start in 2019. The four scenarios are unilateral steel and aluminum tariffs by the U.S., scenario 1 plus retaliatory tariffs by China, the EU, Canada, and Mexico, scenario 2 plus US-China trade conflict, and scenario 3 plus 25 percent US tariff increase on automobiles and parts imports from the EU. In these scenarios, the impact of the trade conflict on the two major economies results also in marginal, and the U.S. economy is less vulnerable than the Chinese economy. The scenario 4 subtracts the former with -0.3 percent and the latter with -1.3 percent (Bollen, Rojas-Romagosa, 2018, table 3].

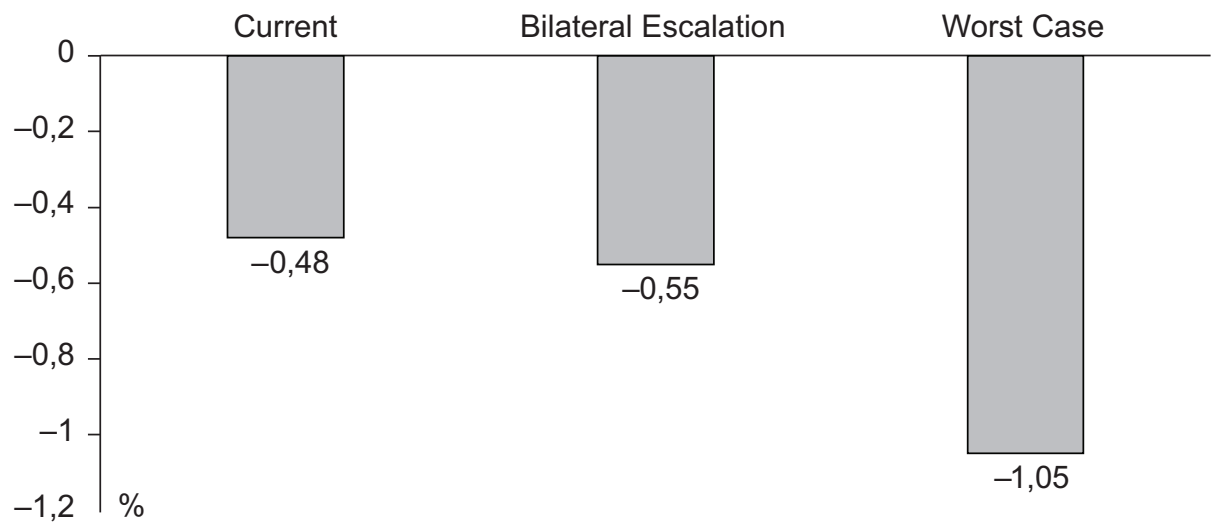

Direct, indirect, and trade redirection effects

Fig. 3. Impact of the Trade Conflict on Chinese GDP by Scenarios

Source: [Abiad et al., 2018].

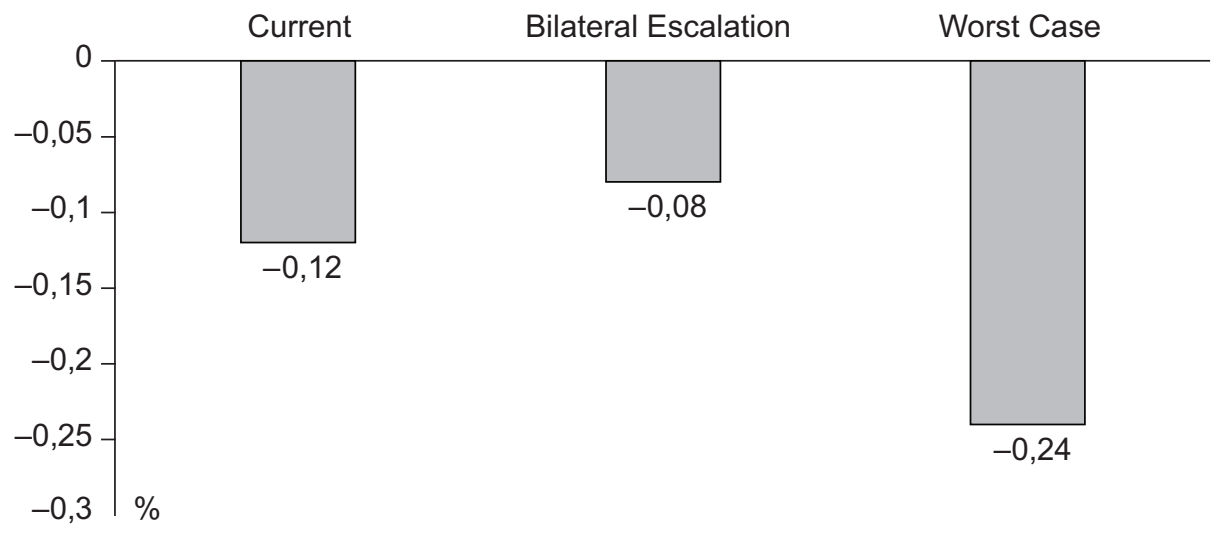

Direct, indirect, and trade redirection effects

Fig. 4. Impact of the Trade Conflict on the U.S. GDP by Scenarios

Source: [Abiad et al., 2018].

Besides these four scenarios, there is scenario for trade conflict escalation between the U.S. and all OECD member nations including trade conflict escalation between the U.S. and China. In the scenario, the impact of the trade conflict on the two major economies could be 
rather strong. It could subtract the U.S. economic growth with slightly over three percent, while the Chinese economy could generate over four percent economic growth loss [Bollen, RojasRomagosa, 2018].

Table 3. Macroeconomic Effects of the U.S. and China Compared to the Baseline in 2030

\begin{tabular}{|l|c|c|}
\hline \multicolumn{1}{|c|}{ Scenarios } & The U.S. & China \\
\hline Scenario 1 & & 0.0 \\
\hline GDP (\%) & 0.0 & 0.0 \\
\hline Export volume (\%) & -1.6 & 0.0 \\
\hline Import volume (\%) & -1.0 & 0.2 \\
\hline Scenario 2 & -0.4 & -0.9 \\
\hline GDP (\%) & -6.3 & -0.9 \\
\hline Export volume (\%) & -4.8 & -1.2 \\
\hline Import volume (\%) & & -8.2 \\
\hline Scenario 3 & -0.3 & -8.4 \\
\hline GDP (\%) & -13.5 & \\
\hline Export volume (\%) & -10.5 & -1.3 \\
\hline Import volume (\%) & & -8.3 \\
\hline Scenario 4 & -0.3 & -8.4 \\
\hline GDP (\%) & -14.0 & \\
\hline Export volume (\%) & -10.9 & \\
\hline Import volume (\%) & & \\
\hline
\end{tabular}

Source: [Bollen, Rojas-Romagosa, 2018] based on World Scan simulations.

\section{Impacts on the World Economy}

Given the ADB analysis, the trade conflict between the two economies will be affected negatively in all scenarios even in the world economy although it will affect to the world economy less than to the U.S. and Chinese economies. Under the current scenario, the global economy would grow lower GDP by 0.08 percent, while the bilateral escalation scenario subtracts 0.07 percent GDP. In the worst case scenario, the world economic growth could be less by 0.25 percent. It shows that the trade conflict between the two largest economies will impact on the global economy nearly zero in the two scenarios, but affect very low in the worst case scenario in the midterm period. In the World Scan simulation, the impact of the trade conflict on the world economy could be from -0.1 percent negative economic growth to 0.1 percent economic growth in all scenarios [Abiad et al., 2018; Bollen, Rojas-Romagosa, 2018, fig. 5, 6].

Although the world economic growth ranges from -0.1 percent to 0.1 percent based on the World Scan simulation, some part of the world could be affected more negatively than other part of the world. East Asian countries supplying intermediate goods to China and exporting final products to the U.S. and the EU could be affected mostly negative. These nations are Korea, Japan, Singapore and Taiwan. Additionally, Australia, Indonesia, Thailand, and the Philippines exporting raw materials and industrial parts to China will be impacted negatively [Bollen, Rojas-Romagosa, 2018; IMF, 2019]. 


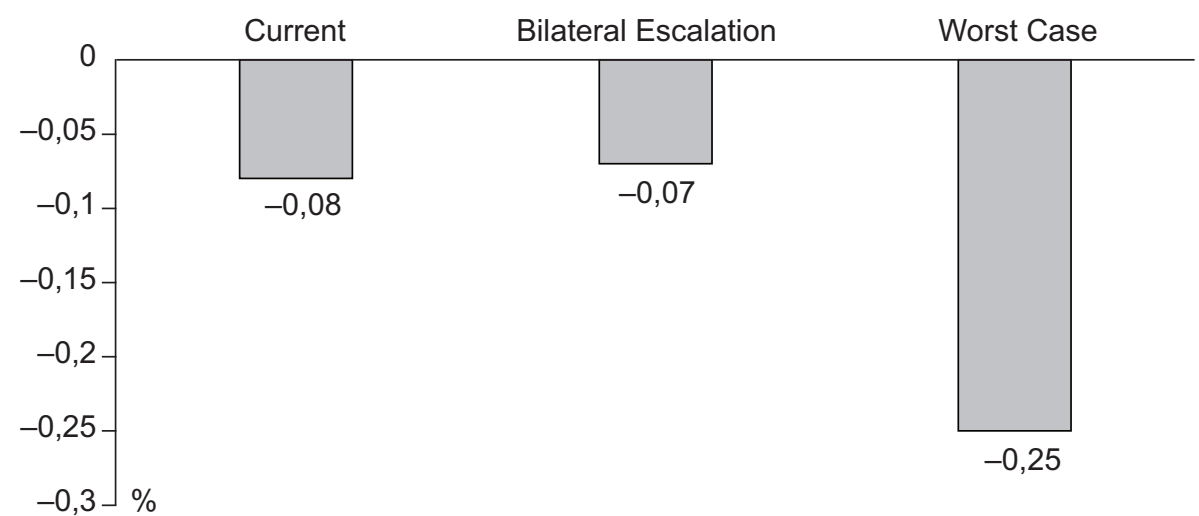

Direct, indirect, and trade redirection effects

Fig. 5. Impact of the Trade Conflict on the World GDP by Scenarios

Source: [Abiad et al., 2018].

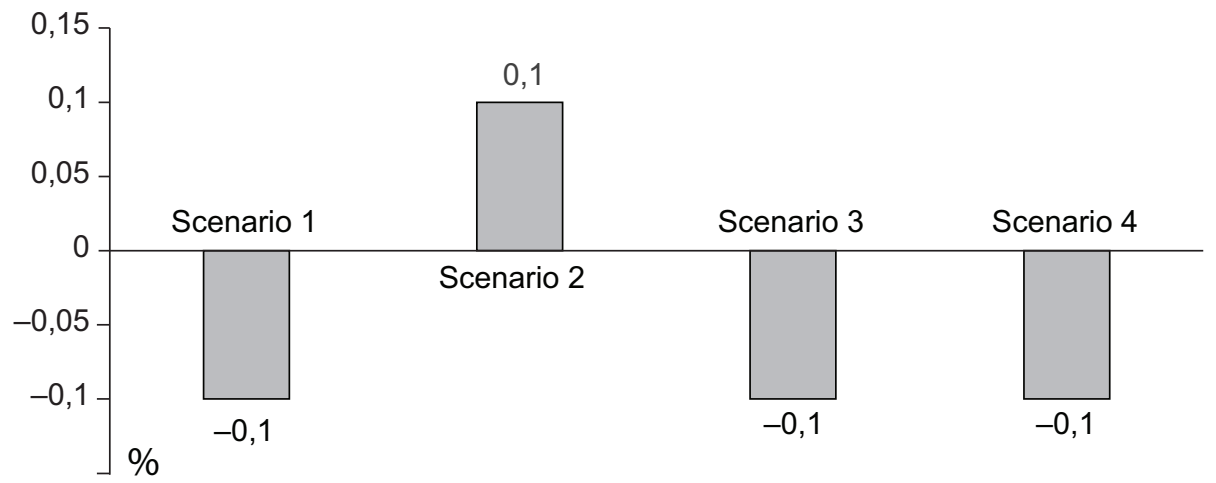

Fig. 6. Macroeconomic Effects of the World Economy Compared to the Baseline in 2030

Source: [Bollen, Rojas-Romagosa, 2018] based on World Scan simulations.

\section{Conclusion}

Trade conflict has always existed in the global economy that is rather common because some trading partners gain more benefit than others. In the economic history, our lesson is that there is no winner from the trade conflict if it is not solved by dialogue and trade agreements. We have already experienced the Great Depression in 1929/1930 that resulted in the Second World War and the total destruction of the world economy. Unfortunately, we are again experiencing severe trade conflicts between the two largest economies in the $21^{\text {st }}$ century that may impact on the global economy negatively if it continues without any proper solution.

First of all, ironically the trade conflict started from the U.S. pursuing trade protectionism particularly in the Trump Administration having various internal problems such as trade imbalance with its trading partners, income inequality, a vast government budget deficit etc. The U.S. government imposed high tariffs on imports of solar panel and washing machine first and later steel and aluminum from imports of its trading partners. After revising KORUS FTA and NAFTA, the U.S. government focuses on the trade dispute with China that is still ongoing 
process threatening to impose 25 percent tariff on all import goods from China and vice versa. Furthermore, the U.S. government plans to impose 25 percent tariff on the import of automobiles and parts from all countries although it is delayed six months long from May 2019.Fortunately, the two nations agreed the trade deal and signed on it in Jan 2020 in order to solve the trade conflict. However, it is not fully clear that the trade deal could be implemented as planned because the two parties' interests are not fully matched.

Since the severe trade conflict between the U.S. and China started in early 2018, several global and regional institutes such as IMF, ADB, European Central Bank (ECB) started to analyze the impacts of the trade conflict between the two major economies as well as the global economy. Additionally, individual nations' economic think tanks also joined this trend.For the impact of the trade conflict between G2 on their national economies and the global economy in the midterm period, the analysis of ADB predicted a minor economic impact on the U.S. and China in the three scenarios although impact on China could be higher than that of the U.S. Additionally, the impact of the world economy in these scenarios could be very low. It may be the reason why the two major economies are not afraid of continuing the trade conflict because the trade conflict in all scenarios could impact on their economies marginal. Based on this reason, the trade conflict between the U.S. and China may continue at least in the midterm period if the both parties are not satisfied with the final outcome of their trade negotiation.

In the longer term perspective based on the World Scan simulations, the trade conflict between the two major economies could also generate marginal impacts on the U.S. and Chinese economies, while it would affect the global economy negatively except the scenario 2 . However, the worst case is that the U.S. escalates trade conflict with all OECD member nations including the U.S. and China trade conflict escalation resulting in the impacts of high GDP loss on the U.S. and China with over three percent, and four percent respectively. Therefore, it is extremely important not only for the two major economies, but also for global economy to hinder the trade conflict from escalating and spreading out at the global level.

In fact, the trade conflict between G2 generates other issues such as technological dispute, financial conflict focusing on currency manipulation etc. In terms of the technological conflict, G2 competes with each other particularly in the $5 \mathrm{G}$ area that plays the core role in completing the Fourth Industrial Revolution. At present, China is ahead the U.S. in the area so that the U.S. government has tackled on suspending Chinese Huawei in the U.S. market due to the national security reason and asked its allies to follow the U.S. policy line. It means that the trade conflict is only a starting point for the technological supremacy and hegemonies power in the world politics and economy. Accordingly, it will spread out to other areas such as technology and finance continuously in the future.

\section{References}

Abiad A., Baris K., Bernabe J.A., Bertulfo D.J., Camingue-Romance S., Feliciano P.N., Mariasingham M.J., Mercer-Blackman V. (2018) The Impact of Trade Conflict on Developing Asia. Asian Development Bank Economics Working Paper Series, no 566, Dec., Manila: ADB.

Acemoglu D. (2009) Modern Economic Growth. Princeton, NJ: Princeton University Press.

Alvaredo F., Chancel L., Piketty T., Saez E., Zucman G. (2017) World Inequality Report 2018. Available at: https://wir2018.wid.world/files/download/wir2018-full-report-english.pdf (accessed on 22 May 2019).

Amadeo K.Y. (2019) US trade Deficit with China and Why It's So High. Available at: https://www.thebalance. com/u-s-china-trade-deficit-causes-effects-and-solutions-3306277 (accessed on 21 May 2019).

Bezlova A. (2007) China: Headed for Trade Wars with the U.S. Inter Press Service. April 27.

Bhagwati J. (2009) Does the U.S Need a New Trade Policy? Journal of Policy Modeling, vol. 31, no 4, pp. $509-514$. 
Bolt W., Mavromatis K., van Wijnbergen S. (2019) The Global Macroeconomics of Trade War: The EAGLE Model on the U.S. - China Trade Conflict. Available at: https://www.dnb.nl/binaries/wp623_tcm46-381884.pdf (accessed on 16 May 2019).

Bollen J., Rojas-Romagosa H. (2018) Trade Wars: Economic Impacts of US Tariff Increases and Retaliation: An International Perspective. CPB Background Document, Nov. Amsterdam: CPB Netherlands Bureau for Economic Policy Analysis.

Bown C.P., Kolb M. (2018) Trump's Trade War Timeline: An Up-to-date Guide. Peterson Institute for International Economics. Available at: https://piie.com/system/files/documents/trump-trade-war-timeline.pdf (accessed on 11 May 2019).

Bradford S., Greico P., Hufbauer G.C. (2006) The Payoff to America from Globalisation. The World Economy, vol. 29, no 7, pp. 893-917.

Broda C., Weinstein D.E. (2006) Globalization and the Gainsfrom Variety. The Quarterly Journal of Economics, vol. 121, no 2, pp. 541-585.

Cong W. (2019) Retaliation on American Firms Suggested After Huawei Ban. Global Times. May 17. Available at: http://www.globaltimes.cn/content/1150422.shtml (accessed on 18 May 2019).

Doffman Z. (2019) Trump signs Executive Order That Will Lead to U.S. Ban on Huawei. May 15. Available at: https://www.forbes.com/sites/zakdoffman/2019/05/15/trump-expected-to-sign-executive-order-leading-toban-on-huawei-this-week/\#497d903168d9 (accessed on 23 May 2019).

Eavis P., Rappeport A., Swanson A. (2020) What's in (and Not in) the US - China Trade Deal, The New York Times. 15 Jan. Available at: https://www.nytimes.com/2020/01/15/business/economy/china-trade-deal-text. html (accessed on 06 March 2020).

European Commission. (2019) EU - China: A Strategic Outlook. Strasbourg: EC.

Economic Report of the President (ERP). (2009) Economic Report of the President Together with the Annual Report of the Council of Economic Advisers. Washington, DC: U.S. Government Printing Office.

Feenstra R.C., Mandel B.R., Reinsdorf M.B., Slaughter M. (2009) Effects of Terms of Trade Gains and Tariff Changes on the Measurement of U.S. Productivity Growth. NBER Working Paper no 15592.

Genereux F. (2017) Protectionism: A Brake on Economic Growth. Economic Studies. 17 February. Available at: https://www.desjardins.com/ressources/pdf/pv170217-e.pdf (accessed on 09 May 2019).

Gomory R., Baumol W. (2009) Globalization: Country and Company Interests in Conflict. Journal of Policy Modeling, vol. 31, no 3, pp. 540-555.

Hanemann T. (2018) Arrested Development: Chinese FDI in the US in 1H 2018. June 19. Available at: https://rhg. com/research/arrested-development-chinese-fdi-in-the-us-in-1h-2018/ (accessed on 24 May 2019).

Hillebrand E.E., Lewer J.J., Zagardo J.T. (2010) Backtracking from Globalization. Global Economy Journal, vol. 10 , no 4 , p. 1 .

Hsieh P.L. (2009) China - United States Trade Negotiations and Disputes: The WTO and Beyond. Asian Journal of WTO and International Health Law and Policy, vol. 4, no 2, pp. 368-399.

Hufbauer G.C., Schott J.J. (2008) What Should Leaders do to Stop the Spread of Protectionism? What World Leaders Must Do to Halt the Spread of Protectionism (R. Baldwin, S. Evenett (eds.)). London: Centre for Economic Policy Research (CEPR). Available at: https://voxeu.org/sites/default/files/file/protectionism.pdf (accessed on 07 May 2019).

International Monetary Fund (IMF). (2015) IMF Executive Board Completes the 2015 Review of SDR Valuation. Press Release no 15/543. Available at: https://www.imf.org/en/news/articles/2015/09/14/01/49/pr15543 (accessed on 04 May 2019).

International Monetary Fund (IMF). (2019) World Economic Outlook: Growth Slowdown, Precarious Recovery. April. Washington, D.C.: IMF.

Jiming H. (2018) China - US Trade Conflict: Causes and Impact, 2018 CF40-PIIE Joint Report. Available at: https://piie.com/system/files/documents/ha20180611ppt.pdf (accessed on 23 May 2019). 
Kirton J. (2013) G20 Governance for a Globalized World. Farnham: Ashgate.

Krugman P.R. (1997) Increasing Returns, Monopolistic Competition, and International Trade. Journal of International Economics, vol. 9, no 4, pp. 469-479.

Krugman P.R., Obstfeld M. (2009) International Economics, Boston, MA: Pearson, Addison-Wesley.

Lewer J.J., Van den Berg H. (2007) International Trade and Economic Growth, Armonk, NY: M.E. Sharpe.

Martin M.F. (2018) What's the Difference? - Comparing U.S. and Chinese Trade Data, CRS Report, RS 22640, Washington D.C.: CRS.

Momani B. (2016) China at the IMF // Enter the Dragon: China in the International Financial System (D. Lombardi, H.-Y. Wang (eds.)). Montreal \& Kingston: McGill Queen's Press, pp. 267-288.

Ng T., Chung K. (2018) Trade Conflict between China and the United States and Its Impact on Hong Kong's Economy. Hong Kong: Research Office, Legislative Council Secretariat. Available at: https://www.legco.gov. $\mathrm{hk} /$ research-publications/english/1718in14-trade-conflict-between-china-and-the-united-states-and-itsimpact-on-hong-kongs-economy-20180717-e.pdf (accessed on 11 May 2019).

Office of the United States Trade Representative \& Department of Treasury. (2020) Economic and Trade Agreement Between the United States of America and the People's Republic of China. Available at: https://int.nyt.com/ data/documenthelper/6667-us-china-trade-deal/b8ef0d1826ca2b48f121/optimized/full.pdf (accessed on 06 March 2020).

Organization for Economic Cooperation and Development (OECD). (2014) Fact Book 2014. Paris: OECD.

O'Rourke K.H., Williamson J.G. (2001) Globalization and History: The Evolution of Nineteenth Century Atlantic Economy. Cambridge, MA: The MIT Press.

Park S.-C. (2017) Can Trade Help Overcome Economic Crisis? Implications for Northeast Asia Creating Regional FTA between Korea, China, and Japan and Mega FTAs such as RCEP and TPP. International Organizations Research Journal, vol. 12, no 2, pp. 104-128.

Park S.-C. (2018) U.S. Protectionism and Trade Imbalance between the U.S. and Northeast Asian Countries. International Organizations Research Journal, vol. 13, no 2, pp. 76-100.

Piketty T. (2014) Capital in the Twenty First Century. Cambridge, MA: Belknap Press.

Rosen H. (2008) Strengthening Trade Adjustment Assistance. Washington, D.C.: Peterson Institute for International Economics Policy Brief, PD 09-2, January.

Salama V., Mauldin W. (2019) Trump Administration Delays Decision on Car Tariffs. The Wall Street Journal. May 15.

Samuelson P. (2004) Where Ricardo and Mill Rebut and Confirm Arguments of Mainstream Economists Supporting Globalization. Journal of Economic Perspectives, vol. 18, no 3, pp. 135-146.

Schwab K. (2016) The Fourth Industrial Revolution. Geneva: World Economic Forum.

Stewart H. (2006) U.S. - China Trade War Looms. The Observer. March 26.

Strauss D. (2019) Global Economy Counts Cost of Trade Dispute. Financial Times. 10 May.

The White House. (2017) National Security Strategy of the United States of America. Washington, D.C.: The White House. Available at: https://www.whitehouse.gov/wp-content/uploads/2017/12/NSS-Final-12-18-2017-0905. pdf (accessed on 23 May 2019).

United States Census Bureau. (2019) Foreign Trade. Available at: https://www.census.gov/foreign-trade/balance/c5700.html (accessed on 21 May 2019).

US Trade Representative (USTR). (2018) USTR Finalizes Tariffs on \$200 billion of Chinese Imports in Response to China's Unfair Trade Practices. Available at: https://ustr.gov/about-us/policy-offices/press-office/pressreleases/2018/september/ustr-finalizes-tariffs-200 (accessed on 23 May 2019).

Wang Z., Wei S.-J., Zhu K.-F. (2018) Quantifying International Production Sharing at the Bilateral and Sector Levels. National Bureau of Economic Research Working Paper no 19677. Available at: https://www.nber.org/ papers/w19677.pdf (accessed on 25 May 2019.

World Bank. (2019) GINI Index, World Bank Estimate. Available at: https://data.worldbank.org/indicator/ SI.POV.GINI?locations=US (accessed on 22 May 2019). 